\title{
GAYA KOGNITIF FIELD DEPENDENT TERHADAP PEMAHAMAN KONSEP LIMIT MAHASISWA PENDIDIKAN MATEMATIKA
}

\author{
Nurafni \\ Universitas Muhammadiyah Prof. DR. HAMKA \\ avnie_cute20@yahoo.com
}

\begin{abstract}
ABSTRAK
Penelitian ini merupakan penelitian deskriptif dengan pendekatan kualitatif yang bertujuan untuk mendeskripsikan profil pemahaman konsep limit mahasiswa berdasarkan gaya kognitif field dependent. Subjek penelitian ini adalah mahasiswa Pendidikan Matematika semester II UHAMKA Jakarta. Penelitian dimulai dengan menentukan subjek penelitian menggunakan instrumen GEFT serta kesediaan mahasiswa dan hasil konsultasi dengan dosen bidang studi, Kemudian dilanjutkan dengan pemberian tes pemahaman konsep limit fungsi (TPKLF) dan wawancara. Pengecekan keabsahan data menggunakan triangulasi waktu. Hasil penelitian menunjukan bahwa Pemahaman mahasiswa dengan gaya kognitif field dependent terhadap konsep limit ketika menyatakan makna limit yang diberikan menggunakan bahasanya sendiri hanya terpaku pada notasi limit yang diberikan. Subjek tidak dapat dapat mengkaitkan antar apa yang diketahui dalam soal dengan informasi lain yang diberikan. Ketika menggunakan konsep limit untuk menyelesaikan masalah yang diberikan, subjek tidak memenuhi indikator ini dikarenakan subjek menggunakan cara prosedural bukan menggunakan konsep limit yang diketahuinya. Ketika menggunakan syarat perlu atau syarat cukup untuk menentukan ada atau tidaknya suatu limit subjek mampu menggunakan syarat perlu jika limit tersebut tidak memiliki syarat yang berbeda. Jika limit yang diberikan memiliki syarat yang berbeda, subjek tersebut tidak dapat menggunakan syarat perlu untuk menentukan ada atau tidaknya suatu limit. Hasil penelitian menunjukan bahwa mahasiswa dengan gaya kognitif field dependent tidak memenuhi seluruh indikator pemahaman konsep limit.
\end{abstract}

Kata Kunci : pemahaman konsep, limit, field dependent.

\section{PENDAHULUAN}

Seorang dosen perlu memperhatikan perkembangan berpikir aljabar mahasiswanya. Berpikir aljabar penting untuk diperhatikan karena seperti yang diungkapkan Kamol, dkk (2003) bahwa aljabar memainkan peranan penting dalam kurikulum sekolah sehingga pendidik perlu memperhatikan berpikir aljabar peserta didiknya.

Matematika merupakan salah satu ilmu dasar yang telah berkembang pesat dan digunakan oleh berbagai bidang keilmuan. Matematika pada perguruan tinggi terdiri atas bagian-bagian matematika yang dipilih guna menumbuh-kembangkan kemampuankemampuan dan membentuk pribadi mahasiswa serta berpadu kepada perkembangan ilmu pengetahuan dan teknologi. Perguruan tinggi menjadi salah satu wadah untuk menumbuhkembangkan kemampuan matematika dalam keberhasilan meningkatkan mutu sumber 
daya manusia. Mutu pendidikan yang baik dapat ditunjang melalui kualitas pemahaman mahasiswa yang baik pula. Berdasarkan hal itu, dosen dituntut untuk dapat memberikan pemahaman kepada mahasiswa melalui berbagai strategi, metode, maupun pendekatan yang diduga cocok untuk proses pembelajaran yang dihadapi. Begitu pula dengan konsep limit, pemahaman mahasiswa dalam konsep ini amatlah penting karena konsep limit merupakan konsep dasar atau pengantar untuk diferensial dan integral pada topik kalkulus.

Pembelajaran konsep limit fungsi diberikan kepada mahasiswa dalam matakuliah Kalkulus I yang diawali dengan menyajikan pengertian tersebut secara intuitif sebelum definisi formal limit fungsi diberikan. Berikut ini, terdapat beberapa hasil penelitian terkait dengan limit fungsi yang menjadi latar belakang masalah yang menurut peneliti perlu mendapat perhatian khusus, diantaranya penelitian yang dilakukan oleh Asdar (2012) dan Minggi (2010).

Penelitian yang dilakukan oleh Asdar (2012) mengungkapkan bahwa salah satu mahasiswa yang menjadi subjek penelitiannya dapat menghitung nilai limit secara prosedural dengan benar, mampu menjelaskan makna limit dengan benar tetapi tidak mampu menggunakan makna limit untuk menyelesaikan masalah yang diberikan. Contohnya mahasiswa tersebut dapat menentukan $\lim _{x \rightarrow 1} f(x)=2$ dengan $f(x)=x+1$ dengan benar (secara prosedural), yaitu dengan cara mensubstitusikan $x=1$ ke dalam $f(x)$. Subjek tersebut juga dapat menyebutkan makna limit dengan benar, yakni "jika nilai-nilai $x$ yang diambil mendekati 1 menyebabkan $f(x)$ mendekati 2". Namun, mahasiswa tersebut menjelaskan bahwa "makna limit apabila digunakan cara substitusi, yaitu $f(x)$ bernilai 2". Hal tersebut menunjukan bahwa mahasiswa tersebut tidak mampu menggunakan manka limit untuk menyelesaikan masalah yang diberikan.

Hasil penelitian lain seperti yang dilakukan oleh Minggi (2010) mengungkapkan bahwa salah satu mahasiswa yang dijadikan subjek penelitiannya, mampu menjelaskan makna limit secara intuitif menggunakan bahasanya sendiri dengan benar kemudian dengan segera merepresentasikan dalam bentuk grafik, akan tetapi ketika dimintai keterangan mengenai grafik yang dibuat, mahasiswa tersebut terlihat bingung dan tidak menggunakan cara sebagaimana saat mahasiswa tersebut menjelaskan makna limit. Sebagai contoh, ketika diberikan $\lim _{x \rightarrow 3} f(x)=7$, mahasiswa tersebut dapat menjelaskan makna limit dengan benar, yakni "jika nilai-nilai $x$ yang diambil mendekati 3 menyebabkan $f(x)$ mendekati 7”. Kemudian mahasiswa tersebut merepresentasikan dalam bentuk grafik sebagai berikut. 


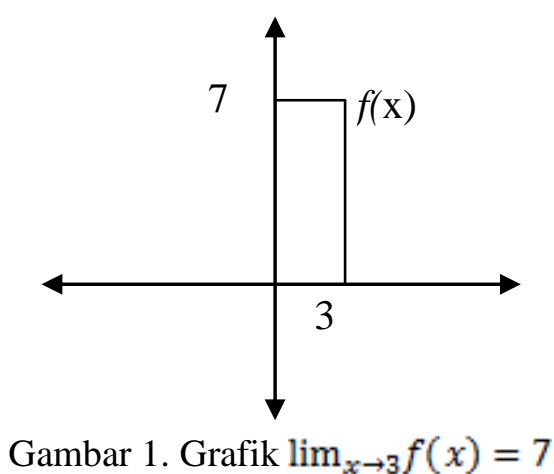

Ketika mahasiswa tersebut diminta menjelaskan mengenai grafik yang dibuat, mahasiswa tersebut menjelaskan "jika nilai x pas dengan 3, nilai limitnya pas dengan 7". Hal tersebut menunjukan bahwa mahasiswa tersebut tidak menggunakan makna limit yang dinyatakan sebelumnya untuk merepresentasikan dalam grafik yang dibuatnya. Terlihat bahwa representasi yang dibuat oleh mahasiswa tersebut tidak terkait dengan makna limit yang diungkapkan sebelumnya. Asdar (2012) menduga bahwa dosen yang mengajarkan konsep limit berpotensi menjustifikasi mahasiswanya telah memahami konsep limit yang diajarkan berdasarkan kemampuannya menyelesaikan soal, menghitung, membuktikan atau menjelaskan konsep-konsep yang terkait dengan limit yang diajarkan, tanpa menyadari adanya kemungkinan mahasiswanya tidak dapat mengintegrasikan pemahamanpemahaman yang dimilikinya terkait dengan konsep limit yang dipelajarinya.

Pengertian pemahaman itu sendiri menurut Panangian (2012) adalah proses, perbuatan, cara memahami atau memahamkan. Sedangkan pengertian pemahaman menurut Suhartini (2007) adalah kemampuan untuk menguasai pengertian. Pemahaman yang akan dikaji dalam penelitian ini adalah kemampuan mahasiswa mengkaitkan informasi tentang obyek dengan skemata yang telah dimiliki sebelumnya. Kesumawati (2008) menyatakan bahwa dalam proses pembelajaran matematika, pemahaman konsep merupakan bagian yang sangat penting. Pemahaman konsep matematika merupakan landasan penting untuk berpikir dalam menyelesaikan permasalahan matematika maupun permasalahan seharihari. Hasil observasi yang dilakukan Susanto (2011) terhadap subjek penelitiannya di Universitas Veteran Bangun Nusantara Sukoharjo dijumpai bahwa dalam proses pembelajaran, dosen belum optimal dalam memperhatikan pemahaman konsep mahasiswamahasiswa yang diajar, sehingga mahasiswa banyak melakukan kesalahan dalam memahami konsep. Berdasarkan hal tersebut dosen harus betul-betul memberikan 
pemahaman konsep kepada mahasiswanya agar kesalahan-kesalahan mengenai pemahaman konsep tidak terjadi lagi.

Darminto (2009) mengungkap bahwa pemahaman konsep merupakan kompetensi yang dimiliki mahasiswa dengan beberapa indikator berikut: (1) menyatakan atau menjelaskan ulang sebuah konsep, (2) mengklasifikasikan sifat-sifat tertentu, (3) memberi contoh, (4) merepresentasikan konsep, (5) menggunakan konsep untuk menyelesaikan masalah.

Selain pentingnya memahami suatu konsep, dosen juga harus memperhatikan gaya kognitif mahasiswanya, karena gaya kognitif juga merupakan salah satu faktor penentu keberhasilan pembelajaran. Seperti yang dikatakan oleh Minggi (2010) bahwa memperhatikan gaya kognitif mahasiswa sangat diperlukan dalam proses pembelajaran, agar materi yang dipelajari dapat dipahami dengan baik dan pengetahuan dapat tersimpan dalam memori jangka panjang secara baik. Susanto (2011) mengungkapkan bahwa dalam belajar matematika, dosen sebaiknya memperhatikan gaya kognitif mahasiswa dengan jalan mendesain pembelajaran yang mempertimbangkan gaya kognitif mahasiswa. Hal tersebut dikarenakan mahasiswa dengan gaya kognitif field dependent cenderung memilih belajar dalam kelompok dan sesering mungkin berinteraksi dengan dosen. Untuk menentukan gaya kognitif individu, sejak 1948, Witkin telah memulai mengembangkan alat ukur untuk membedakan tipe-tipe individu berdasarkan gaya kognitif. Menurut Susanto (2011:42) gaya kognitif field dependent (FD) adalah gaya kognitif individu yang cenderung mudah terpengaruh oleh tugas dan situasi lingkungannya. Hal tesebut sejalan dengan pernyataan dari Candiasa (2002) bahwa gaya kognitif field dependent adalah individu yang cenderung berpikir secara global, memandang obyek dan lingkungannya sebagai satu kesatuan, berorientasi sosial, lebih menginginkan lingkungan yang terstruktur, mengikuti tujuan yang sudah ada, serta mengutamakan motivasi dan penguatan eksternal. Berdasarkan latar belakang yang telah dikemukakan, maka tujuan dalam penelitian ini untuk mendeskripsikan pemahaman konsep limit mahasiswa field dependent (FD).

\section{METODE PENELITIAN}

\section{Jenis Penelitian}

Jenis penelitian ini tergolong penelitian kualitatif karena setting penelitian berlatar alami dan instrumen utama penelitian adalah peneliti sendiri. Dalam hal ini penelitian ini dimaksudkan untuk mendeskripsikan profil pemahaman mahasiswa terhadap konsep limit ditinjau dari perbedaan gaya kognitif field independent (FI) dan field dependent (FD). 


\section{Subjek Penelitian}

Subjek dalam penelitian ini adalah dua orang mahasiswa jurusan Pendidikan Matematika yang terdiri dari mahasiswa dengan gaya kognitif field independent dan field dependent yang berkemampuan sama dan dapat berkomunikasi dengan lancar. Pemilihan subjek penelitian dilakukan berdasarkan skor hasil GEFT yang diberikan. Tes yang diberikan adalah tes gaya kognitif dengan menggunakan instrumen GEFT (Group Embedded Figures Test). Pengelompokan mahasiswa kedalam satu tipe gaya kognitif field independent dan field dependent didasarkan atas kemampuannya dalam menemukan gambar sederhana yang telah disediakan. Pengkategorian atau penggolongan mahasiswa field independent yaitu jika skornya $50 \%<$ gaya kognitif $\leq 100 \%$ dan mahasiswa field dependent jika skornya $0 \% \leq$ gaya kognitif $\leq 50 \%$. Setelah mengetahui hasil kemampuan gaya kognitif diatas, dipilih 1 orang mahasiswa sebagai subjek penelitian dari masingmasing kelompok. Pemilihan subjek didasarkan pada kemampuan matematika mahasiswa yang sama (berdasarkan nilai semester) dan juga mahasiswa yang komunikatif artinya mahasiswa yang mampu mengkomunikasikan pendapatnya secara lisan

Adapun prosedur penelitian yang dilakukan peneliti sebagai berikut :

1. Tahap persiapan

Kegiatan yang dilakukan pada tahap ini adalah :

a. Peneliti meminta surat izin penelitian untuk melakukan penelitian.

b. Peneliti menyusun instrumen penelitian yang meliputi tes GEFT yaitu soal tes penentu gaya kognitif mahasiswa, soal tes pemahaman konsep limit fungsi (TPKLF) dan pedoman wawancara.

c. Melakukan validasi terhadap instrumen penelitian (TPKLF dan pedoman wawancara) yang dilakukan oleh pakar/ahli.

2. Tahap pelaksanaan

Kegiatan yang dilakukan pada tahap ini adalah :

a. Memilih subjek penelitian berdasarkan hasil tes GEFT. Mahasiswa dikelompokkan menjadi dua yaitu mahasiswa dengan gaya kognitif field independent (FI) dan field dependent (FD). Dari dua kelompok tersebut dipilih 1 mahasiswa dari setiap kelompok FI dan FD.

b. Memberikan tes mengenai pemahaman konsep limit fungsi (TPKLF) kepada setiap subjek penelitian. 
c. Melakukan wawancara pada setiap subjek penelitian berdasarkan hasil TPKLF yang diperoleh, wawancara secara lisan untuk menggali tentang apa, bagaimana dan mengapa yang berkaitan dengan permasalahan yang telah diberikan dan hasilnya serta kemungkinan lain yang muncul dari pertanyaan yang diajukan. Wawancara digunakan untuk mendapatkan informasi tentang pemahaman mahasiswa terhadap konsep limit fungsi sebagai bahan untuk menarik kesimpulan.

3. Tahap analisis

Kegiatan yang dilakukan pada tahap ini adalah :

a. Mereduksi data, untuk menajamkan informasi, menggolongkan dan membuang yang tidak perlu serta mengorganisasikan data mentah yang diperoleh pada saat melakukan pengumpulan data.

b. Mengolah dan menganalisis data yang diperoleh dari tahap pelaksanaan yaitu hasil pekerjaan mahasiswa terhadap konsep limit fungsi yang dicapai sesuai dengan metode analisis data yang telah ditentukan. Adapun metode analisis data terhadap hasil pekerjaan mahasiswa terhadap konsep limit fungsi akan dijelaskan lebih lengkap pada bagian metode analisis data dan pembahasan selanjutnya.

c. Mendeskripsikan hasil analisis data.

4. Tahap pembuatan laporan.

\section{HASIL DAN PEMBAHASAN}

\section{Hasil Penelitian}

Berdasarkan hasil tertulis dan wawancara TPKLF I dan TPKLF II yang sudah direduksi, dapat diuraikan data tertulis dan data wawancara tentang pemahaman konsep limit fungsi subjek yang disajikan sebagai berikut.

1. Ketika menyatakan makna limit yang diberikan

Hasil tertulis subjek S2 ketika menyatakan makna limit yang diberikan menggunakan bahasanya sendiri dalam TPKLF I untuk poin c, sebagai berikut:

JS2.1.3:

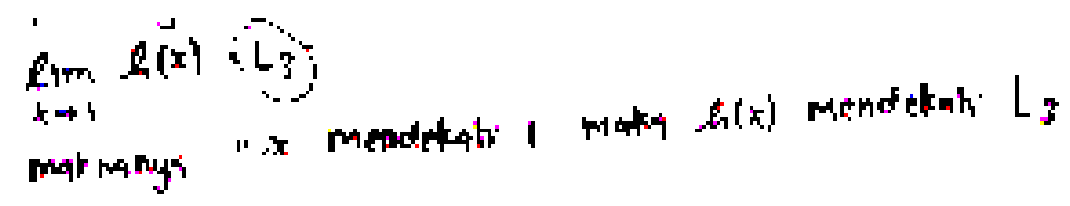

Gambar 2. Jawaban subjek S2.1.3

Cuplikan wawancara subjek S2 ketika menyatakan makna limit yang diberikan menggunakan bahasanya sendiri dalam TPKLF I untuk poin c, sebagai berikut: 
P2.1.38: $\quad$ Bisa dijelaskan makna limit yang ini (menunjuk notasi $\left.\lim _{x \rightarrow 1} h(x)=L_{3}\right)$ ?

S2.1.38: $\quad$ Maknanya itu $x$ mendekati 1 maka $h(x)$ mendekati $L_{3}$.

Paparan data pemahaman subjek ketika menyatakan makna limit yang diberikan pada TPKLF I dan TPKLF II disajikan pada Tabel 1 berikut.

Tabel 1. Paparan Data Pemahaman Subjek ketika Menyatakan Makna Limit yang Diberikan Pada TPKLF I dan TPKLF II

\begin{tabular}{|c|c|}
\hline Data pada TPKLF I & Data pada TPKLF II \\
\hline $\begin{array}{l}\text { Pemahaman subjek pada poin a } \\
\text { Subjek ketika menyatakan makna limit yang diberikan } \\
\text { menggunakan bahasanya sendiri dalam TPKLF I yaitu, } \\
\text { subjek menyatakan makna limit menggunakan bahasanya } \\
\text { sendiri, subjek hanya terfokus pada notasi limit yang } \\
\text { diberikan serta tidak menghiraukan petunjuk lain yang } \\
\text { diberikan dalam soal, seperti terlihat pada JS2.1.2 }\end{array}$ & $\begin{array}{l}\text { Subjek ketika menyatakan makna limit yang diberikan } \\
\text { menggunakan bahasanya sendiri dalam TPKLF II yaitu, subjek } \\
\text { menyatakan makna limit menggunakan bahasanya sendiri, } \\
\text { subjek hanya terfokus pada notasi limit yang diberikan serta } \\
\text { tidak menghiraukan petunjuk lain yang diberikan dalam soal, } \\
\text { seperti terlihat pada JS2.2.1 }\end{array}$ \\
\hline Pemahaman subjek pada poin $b$ & \\
\hline $\begin{array}{l}\text { Subjek ketika menyatakan makna limit yang diberikan } \\
\text { menggunakan bahasanya sendiri dalam TPKLF I yaitu, } \\
\text { subjek menyatakan makna limit menggunakan bahasanya } \\
\text { sendiri, subjek hanya terfokus pada notasi limit yang } \\
\text { diberikan serta tidak menghiraukan petunjuk lain yang } \\
\text { diberikan dalam soal, seperti terlihat pada JS2.1.2 }\end{array}$ & $\begin{array}{l}\text { Subjek ketika menyatakan makna limit yang diberikan } \\
\text { menggunakan bahasanya sendiri dalam TPKLF II yaitu, subjek } \\
\text { menyatakan makna limit menggunakan bahasanya sendiri, } \\
\text { subjek hanya terfokus pada notasi limit yang diberikan serta } \\
\text { tidak menghiraukan petunjuk lain yang diberikan dalam soal, } \\
\text { seperti terlihat pada JS2.2.2 }\end{array}$ \\
\hline $\begin{array}{l}\text { Pemahaman subjek pada poin c } \\
\text { Subjek ketika menyatakan makna limit yang diberikan } \\
\text { menggunakan bahasanya sendiri dalam TPKLF I yaitu, } \\
\text { subjek menyatakan makna limit menggunakan bahasanya } \\
\text { sendiri, subjek hanya terfokus pada notasi limit yang } \\
\text { diberikan serta tidak menghiraukan petunjuk lain yang } \\
\text { diberikan dalam soal, seperti terlihat pada JS } 2.1 .3\end{array}$ & $\begin{array}{l}\text { Subjek ketika menyatakan makna limit yang diberikan } \\
\text { menggunakan bahasanya sendiri dalam TPKLF II yaitu, subjek } \\
\text { menyatakan makna limit menggunakan bahasanya sendiri, } \\
\text { subjek hanya terfokus pada notasi limit yang diberikan serta } \\
\text { tidak menghiraukan petunjuk lain yang diberikan dalam soal, } \\
\text { seperti terlihat pada JS2.2.3 }\end{array}$ \\
\hline
\end{tabular}

Berdasarkan paparan data pada tabel 1 , ada konsistensi ketika menyatakan makna limit pada TPKLF I dan TPKLF II, sehingga dapat dikatakan bahwa data ketika menyatakan makna limit menggunakan bahasa sendiri adalah valid.

2. Menggunakan konsep limit untuk menyelesaikan masalah yang diberikan.

Hasil tertulis subjek S2 ketika menggunakan konsep limit untuk menyelesaikan masalah yang diberikan dalam TPKLF I utnuk poin a, sebagai berikut:

JS2.1.4:

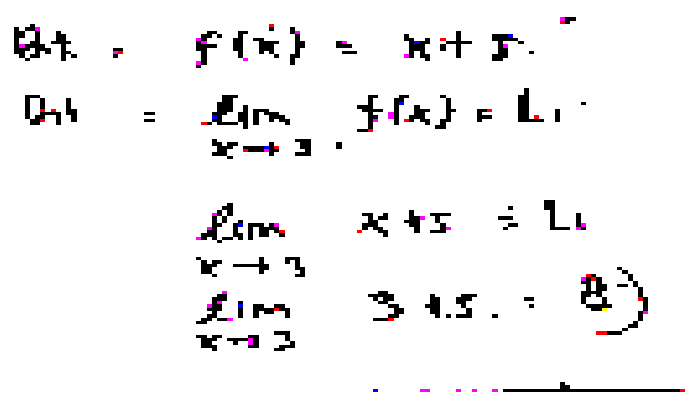

Gambar 3. Jawaban subjek S2.1.4

Cuplikan wawancara subjek S2 ketika menggunakan konsep limit untuk menyelesaikan masalah yang diberikan dalam TPKLF I untuk poin a, sebagai berikut:

P2.1.3: Trus perintah yang kedua carilah $L_{l}$ berdasarkan makna limit yang diketahui, maksudnya apa?

S2.1.3: Mencari $L_{l}$ itu dengan menggunakan makna limit yang saya ketahui. 
P2.1.4: Bagaimana?

S2.1.4: Mencari $L_{1}$, yang diketahuinya $f(x)=x+5$, yang ditanyakan limit $x$ mendekati 3 maka $f(x)$ mendekati $L_{1}$, lalu $f(x)$ nya dimasukan ke $x+5$, dimasukan $x$ nya itu 3 , brarti $3+5=8$ (menunjuk ke JS2.1.4), jadi $x$ mendekati $3, f(x)$ mendekati $L_{l}$ itu 8.

P2.1.5: Cara seperti ini berdasarkan makna limit?

S2.1.5: Iya.

P2.1.6: Jadi Ela tahunya cara substitusi ini adalah cara bedasarkan maknanya?

S2.1.6: Iya.

\section{Paparan data subjek ketika menggunakan konsep limit untuk menyelesaikan} masalah yang diberikan pada TPKLF I dan TPKLF II disajikan pada Tabel 4.15 berikut.

Tabel 2. Paparan Data Pemahaman Subjek ketika Menggunakan Konsep Limit untuk Menyelesaikan Masalah yang Diberikan pada TPKLF I dan TPKLF II

\begin{tabular}{l} 
Data pada TPKLF I \\
\hline Pemahaman subjek pada poin a \\
Subjek menggunakan cara prosedur seperti substitusi \\
untuk menentukan nilai limit $L_{l}$ seperti pada JS2.1.4. \\
Kemudian menggunakan tabel untuk memastikan benar \\
atau tidaknya jawaban yang diketahui menggunakan cara \\
substitusi. Kemudian subjek menerangkan langkah- \\
langkah pengisian tabel yang diawali menentukan nilai $L_{l}$ \\
untuk $x$ mendekati 3 seperti pada S2.1.10. Selain itu subjek \\
menggunakan grafik untuk memastikan benar atau tidaknya \\
jawaban yang diketahui menggunakan cara substitusi dan \\
tabel. Kemudian subjek menerangkan bahwa jika didapat \\
sebuah garis pada grafik maka nilai limit yang didapat pada \\
langkah substitusi adalah benar. Selain itu, subjek \\
menjelaskan bahwa titik potong pada 3,8 merupakan \\
lingkaran penuh karena dari sisi kiri maupun sisi kanan \\
pada grafik menuju 8 .
\end{tabular}

\section{Pemahaman subjek pada poin $b$}

Subjek menggunakan cara turunan seperti yang dilakukan pada JS2.1.7 dengan alasan cara tersebut merupakan cara yang lebih mudah untuk menentukan nilai limit yang dikehendaki soal. Kemudian menggunakan tabel untuk memastikan jawaban yang diperoleh melalui cara turunan seperti pada JS2.1.7 Kemudian mengisi nilai-nilai pada tabel berdasarkan nilai turunan yang didapat dari JS2.1.7 dengan alasan lebih mudah mendapat nilai-nilai pada tabel. Selain itu subjek menggunakan grafik untuk memastikan benar atau tidaknya jawaban yang diketahui menggunakan cara substitusi dan tabel. Kemudian subjek menerangkan bahwa jika didapat sebuah garis pada grafik maka nilai limit yang didapat pada langkah JS2.1.7 adalah benar. Selain itu, subjek menjelaskan bahwa titik potong pada 2,4 merupakan bulatan penuh karena dari sisi kiri maupun sisi kanan pada grafik menuju 4.

\section{Pemahaman subjek pada poin c}

Subjek menggunakan cara prosedur seperti substitusi untuk menentukan nilai limit $L_{3}$. Seperti pada JS2.1.11. Kemudian menggunakan tabel untuk memastikan benar atau tidaknya jawaban yang diketahui menggunakan cara substitusi. Kemudian subjek menerangkan langkahlangkah pengisian tabel yang diawali dengan menentukan nilai $L_{3}$ untuk $x$ mendekati 1 setelah itu nilai-nilai disekitar $x$ mendekati 1 untuk $x \leq 1$. Selain itu Subjek menggunakan grafik untuk memastikan benar atau tidaknya jawaban yang diketahui menggunakan cara substitusi dan tabel. Kemudian subjek menerangkan bahwa jika terdapat dua garis yang berbeda maka nilai limitnya pun berbeda, seperti pada cuplikan S2.1.54. Selain itu, subjek menjelaskan bahwa titik 1,3 dan 1,7 pada grafik merupakan merupakan bulatan penuh karena menuju arah yang positif. Data pada TPKLF II

Subjek menggunakan cara prosedur seperti substitusi untuk menentukan nilai limit $L_{l}$ seperti pada JS2.2.4. Kemudian menggunakan tabel untuk memastikan benar atau tidaknya jawaban yang diketahui menggunakan cara substitusi. Kemudian subjek menerangkan langkah-langkah pengisian tabel yang diawali menentukan nilai $L_{l}$ untuk $x$ mendekati 3 seperti pada S2.2.10. Selain itu subjek menggunakan grafik untuk memastikan benar atau tidaknya jawaban yang diketahui menggunakan cara substitusi dan tabel. Kemudian subjek menerangkan bahwa jika didapat sebuah garis pada grafik maka nilai limit yang didapat pada langkah substitusi adalah benar. Selain itu, subjek menjelaskan bahwa titik potong pada 3,10 merupakan lingkaran penuh karena dari sisi kiri maupun sisi kanan pada grafik menuju 10.

Subjek menggunakan cara turunan seperti yang dilakukan pada JS2.2.8 dengan alasan cara tersebut merupakan cara yang lebih mudah untuk menentukan nilai limit yang dikehendaki soal. Kemudian menggunakan tabel untuk memastikan jawaban yang diperoleh melalui cara turunan seperti pada JS2.2.8 kemudian mengisi nilai-nilai pada tabel berdasarkan nilai turunan yang didapat dari JS2.2.8 dengan alasan lebih mudah mendapat nilai-nilai pada tabel. Selain itu subjek menggunakan grafik untuk memastikan benar atau tidaknya jawaban yang diketahui menggunakan cara substitusi dan tabel. Kemudian subjek menerangkan bahwa jika didapat sebuah garis pada grafik maka nilai limit yang didapat pada langkah JS2.2.8 adalah benar. Selain itu, subjek menjelaskan bahwa titik potong pada 3,6 merupakan bulatan penuh karena dari sisi kiri maupun sisi kanan pada grafik menuju 6 .

Subjek menggunakan cara prosedur seperti substitusi untuk menentukan nilai limit $L_{3}$ seperti pada JS2.2.12. Kemudian menggunakan tabel untuk memastikan benar atau tidaknya jawaban yang diketahui menggunakan cara substitusi. Kemudian subjek menerangkan langkah- langkah pengisian tabel yang diawali dengan menentukan nilai $L_{3}$ untuk $x$ mendekati 1 setelah itu nilai-nilai disekitar $x$ mendekati 1 untuk $x \leq 1$. Selain itu Subjek menggunakan grafik untuk memastikan benar atau tidaknya jawaban yang diketahui menggunakan cara substitusi dan tabel. Kemudian subjek menerangkan bahwa jika terdapat dua garis yang berbeda maka nilai limitnya pun berbeda, seperti pada cuplikan S2.1.59. Selain itu, subjek menjelaskan bahwa titik 1,4 dan 1,5 pada grafik merupakan merupakan bulatan penuh karena menuju arah yang positif. 
Berdasarkan paparan data pemahaman subjek pada Tabel 4.15, ada konsistensi pemahaman subjek ketika menggunakan konsep limit untuk menyelesaikan masalah yang diberikan pada TPKLF I dan TPKLF II, sehingga dapat dikatakan bahwa data pemahaman subjek ketika menggunakan konsep limit untuk menyelesaikan masalah yang diberikan adalah valid.

3. Subjek FD ketika menggunakan syarat perlu atau syarat cukup suatu konsep untuk menentukan ada atau tidaknya suatu limit.

Paparan data subjek ketika menggunakan syarat perlu atau syarat cukup suatu konsep untuk menentukan ada atau tidaknya suatu limit pada TPKLF I dan TPKLF II disajikan pada tabel 3 berikut.

Tabel 3. Paparan Data Pemahaman Subjek ketika Menggunakan Syarat Perlu atau Syarat Cukup Suatu Konsep untuk Menentukan Ada atau Tidaknya Suatu Limit pada TPKLF I dan TPKLF II

\section{Data pada TPKLF I}

Pemahaman subjek pada poin a

Subjek menjelaskan bahwa ada atau tidaknya suatu limit pada $L_{l}$ dapat diketahui dengan melihat limit kiri dan limit kanannya, tidak cukup jika hanya melihat salah satu limit (limit sepihak) seperti terlihat pada cuplikan wawancara S2.1.20

\section{Pemahaman subjek pada poin b}

Subjek menjelaskan bahwa ada atau tidaknya suatu limit pada $L_{2}$ dapat diketahui dengan melihat limit kiri dan limit kanannya, tidak cukup jika hanya melihat salah satu limit (limit sepihak) seperti terlihat pada cuplikan wawancara S2.1.36

\section{Pemahaman subjek pada poin c}

Subjek berpendapat bahwa $L_{3}$ tidak memiliki limit karena memiliki arah yang berbeda seperti terlihat pada cuplikan wawancara S2.1.41

\section{Data pada TPKLF II}

Subjek menjelaskan bahwa ada atau tidaknya suatu limit pada $L_{l}$ dapat diketahui dengan melihat limit kiri dan limit kanannya, tidak cukup jika hanya melihat salah satu limit (limit sepihak) seperti terlihat pada cuplikan wawancara S2.2.22

Subjek menjelaskan bahwa ada atau tidaknya suatu limit pada $L_{2}$ dapat diketahui dengan melihat limit kiri dan limit kanannya, tidak cukup jika hanya melihat salah satu limit (limit sepihak) seperti terlihat pada cuplikan wawancara S2.2.48

Subjek berpendapat bahwa $L_{3}$ tidak memiliki limit karena memiliki arah yang berbeda seperti terlihat pada cuplikan wawancara S2.2.61

Berdasarkan paparan data pada tabel 3, ada konsistensi ketika menggunakan syarat perlu atau syarat cukup suatu konsep untuk menentukan ada atau tidaknya suatu limit pada TPKLF I dan TPKLF II, sehingga dapat dikatakan bahwa data ketika menggunakan syarat perlu atau syarat cukup suatu konsep untuk menentukan ada atau tidaknya suatu limit adalah valid.

\section{Pembahasan}

Berdasarkan hasil penelitian yang telah dilakukan, terungkap bahwa pemahaman subjek field dependent terhadap konsep limit pada indikator pertama yaitu menyatakan makna limit yang diberikan menggunakan bahasanya sendiri hanya terpaku pada notasi limit yang diberikan, sehingga subjek tidak dapat mengkaitkan antara fungsi yang diketahui dengan notasi limit yang diberikan. 
Sedangkan jika diamati pada indikator kedua, yaitu pada saat menggunakan konsep limit untuk menyelesaikan masalah yang diberikan. Subjek ini menentukan nilai limit yang diberikan dengan menggunakan cara prosedural seperti substitusi, subjek tersebut tidak dapat menggunakan atau mengkaitkan makna limit yang diketahuinya untuk menentukan nilai limit yang diminta. Selain dari itu, subjek ini menggunakan tabel dan grafik bukan untuk mencari nilai limit yang diminta tetapi untuk membuktikan nilai limit yang telah diketahui berdasarkan cara substitusi, kemudian subjek berpendapat bahwa suatu titik pada grafik fungsi merupakan bulatan penuh jika limit kiri sama dengan limit kanannya. Selain dari itu, subjek ini juga berpendapat bahwa nilai limit yang didapatnya adalah benar jika garis pada grafik fungsi berupa garis lurus.

Pada indikator ketiga yaitu pada saat menggunakan syarat perlu atau syarat cukup suatu konsep untuk menentukan ada atau tidaknya suatu limit, terungkap bahwa Subjek field dependent menggunakan syarat perlu untuk menentukan ada tidaknya suatu limit. Selain dari itu, subjek tersebut menerangkan bahwa limit pada $L_{1}$ dan $L_{2}$ ada dikarenakan limit kiri sama dengan limit kanan tetapi pada $L_{3}$ tidak terdapat limit dikarenakan subjek tersebut berpendapat bahwa limit tersebut memiliki arah yang berbeda yang menyebabkan nilai limit tersebut tidak ada. Sehingga dapat disimpulkan bahwa subjek ini mampu menggunakan syarat perlu untuk menentukan suatu limit jika limit tersebut tidak memiliki syarat yang berbeda.

Hal ini sesuai dengan pendapat yang dikemukakan Abidin (2012) yaitu gaya kognitif field depedent adalah karakteristik individu yang cenderung sulit untuk menemukan bagian sederhana dari konteks aslinya atau mudah terpengaruh oleh manipulasi unsur-unsur pengecoh pada konteks karena memandangnya secara global.

\section{KESIMPULAN}

Berdasarkan hasil analisis dan pembahasan di atas, peneliti membuat kesimpulan tentang pemahaman mahasiswa dengan gaya kognitif field independent dan field dependent terhadap konsep limit sebagai berikut:

1. Pemahaman subjek field dependent ketika menyatakan makna limit yang diberikan menggunakan bahasa sendiri.

Subjek field dependent menyatakan makna limit yang diberikan menggunakan bahasa sendiri dan hanya terpaku pada notasi limit yang diberikan, subjek ini tidak memperhatikan hal-hal lain dalam soal seperti memperhatikan apa yang diketahui dalam 
soal, sehingga tidak dapat mengkaitkan antara fungsi yang diketahui dengan notasi limit yang diberikan.

2. Pemahaman subjek field dependent ketika menggunakan konsep limit untuk menyelesaikan masalah yang diberikan.

Subjek field dependent tidak menggunakan konsep limit untuk menyelesaikan masalah yang diberikan. Seperti terlihat ketika Subjek ini menentukan nilai limit yang diberikan dengan menggunakan cara prosedural seperti substitusi, subjek tersebut tidak dapat menggunakan atau mengkaitkan makna limit yang diketahuinya untuk menentukan nilai limit yang diminta. Selain dari itu, subjek ini menggunakan tabel dan grafik bukan untuk mencari nilai limit yang diminta tetapi untuk membuktikan nilai limit yang telah diketahui berdasarkan cara substitusi. Selain dari itu, subjek ini juga berpendapat bahwa nilai limit yang didapatnya adalah benar jika garis pada grafik fungsi berupa garis lurus.

3. Pemahaman subjek field dependent ketika menggunakan syarat perlu atau syarat cukup suatu konsep untuk menentukan ada atau tidaknya suatu limit

Subjek field dependent menggunakan syarat perlu atau syarat cukup suatu konsep untuk menentukan ada atau tidaknya limit pada $L_{1}$ dan $L_{2}$. Sebagai contoh, terlihat pada saat subjek menggunakan grafik sebagai representasi untuk mengetahui ada atau tidaknya nilai suatu limit dengan melihat titik-titik dipersekitaran $x$ mendekati 3 melalui garis yang ada pada grafik. Subjek tidak menggunakan syarat perlu atau syarat cukup suatu konsep untuk menentukan ada atau tidaknya limit pada $L_{3}$. Seperti terlihat pada saat subjek berpendapat bahwa limit tersebut memiliki arah yang berbeda yang menyebabkan nilai limit tersebut tidak ada.

4. Terlihat gambaran bahwa subjek dengan gaya kognitif field dependent menyatakan makna limit yang diberikan menggunakan bahasanya sendiri dan hanya terpaku pada notasi limit yang diberikan. Kemudian subjek field dependent tidak menggunakan konsep limit untuk menyelesaikan masalah yang diberikan, melainkan menggunakan cara prosedural seperti substitusi ataupun turunan. Kemudian subjek ini menggunakan syarat perlu untuk menentukan suatu limit jika limit tersebut tidak memiliki syarat yang berbeda.

\section{REKOMENDASI}

Berdasarkan kesimpulan hasil penelitian di atas, saran yang dapat dikemukakan adalah Mahasiswa dengan gaya kognitif field dependent disarankan agar sering diberikan 
latihan soal yang melibatkan pemahaman konsep seperti melatih mahasiswa untuk menyatakan ulang konsep yang dimilikinya dalam berbagai bentuk representasi, jika dimungkinkan sebaiknya menggunakan media pembelajaran seperti alat peraga atau portofolio agar dapat meningkatkan pemahaman mahasiswa dalam menyelesaikan masalah yang dihadapi khususnya terhadap konsep limit.

\section{REFERENSI}

Abidin, Z. (2012). Intuisi Siswa dalam Pemecahan Masalah Matematika Divergen Berdasarkan Gaya Kognitif Field Independent dan Field Dependent. Disertasi. Universitas Negeri Surabaya.

Asdar. (2012). Profil Konflik Kognitif Mahasiswa dalam Pemahaman Limit Ditinjau dari Perbedaan Kemampuan Kalkulus. Ringkasan Disertasi. Universitas Negeri Surabaya.

Darminto, B. P. (2009). Upaya Peningkatan Pemahaman Konsep Aljabar dan Sikap Mahasiswa Calon Guru Matematika terhadap Pembelajaran Berbasis Komputer. Dipresentasikan dalam Seminar Nasional Aljabar, Pengajaran dan Terapannya. Jurusan Pendidikan Matematika Fmipa UNY Yogyakarta

Kesumawati, N. (2008). Pemahaman Konsep Matematik Dalam Pembelajaran Matematika. Semnas Matematika dan Pendidikan Matematika 2008.

Minggi, I. (2010). Profil Intuisi Mahasiswa dalam Memahami Konsep Limit Fungsi Berdasarkan Perbedaan Gender. Disertasi. Universitas Negeri Surabaya.

Panangian, R. (2012). Pengaruh Kecerdasan Emosional dan Kecerdasan Spiritual terhadap Tingkat Pemahaman Akuntansi Pendidikan Tingkat Akuntansi. Artikel Ilmiah Sekolah Tinggi Ilmu Ekonomi Perbanas Surabaya.

Suhartini, A. (2007). Belajar Tuntas: Latar Belakang, Tujuan, dan Implikasi. Lentera Pendidikan, 10(1), Juni, hal. 1-14.

Susanto, H. A. (2011). Pemahaman Mahasiswa dalam Pemecahan Masalah Pembuktian pada Konsep Grup Berdasarkan Perbedaan Gaya Kognitif. Disertasi. Universitas Negeri Surabaya. 